\title{
Fractures of the femoral head: what are the reasons for poor outcome?
}

\author{
Femur başı kırıkları: Tedavi stratejisi ne olmalıdır?
}

\author{
Mert ÖZCAN, Cem ÇOPUROĞLU, Kenan SARIDOĞAN
}

\section{BACKGROUND}

In this article, we aimed to discuss treatment strategies in fracture of the femoral head, which is a very rare injury.

\section{METHODS}

We reviewed five patients (six fractures) who admitted to our emergency department due to femoral head fracture between March 2006 and December 2007. Functional outcomes of the patients who were treated operatively and nonoperatively were compared.

\section{RESULTS}

Half of the fractures were treated nonoperatively and half of them surgically. We observed a rate of $50 \%$ excellent to good results. Avascular necrosis developed in a patient with bilateral injury. The functional results were poor for this patient. Early posttraumatic arthritis was observed in a patient who was treated surgically; this patient had moderate results.

\section{CONCLUSION}

We should aim at anatomic reduction of the fragments with minimum soft tissue injury. The best approach should be chosen for excellent view of the fragments. We should not forget that half of these patients will have a poor outcome despite all treatment strategies.

Key Words: Femur head; fracture; Pipkin; outcome.

\section{AMAÇ}

Bu yazıda, çok nadir bir yaralanma olan femur başı kırıklarında tedavi stratejilerinin tartışılması amaçlandı.

\section{GEREÇ VE YÖNTEM}

Mart 2006 ile Aralık 2007 arasında acil servise femur başı kırı̆ğ ile başvuran beş hastanın altı kırığı incelendi. Cerrahi ve cerrahi dışı yöntemlerle tedavi edilen hastaların fonksiyonel sonuçları karşılaştırıldı.

\section{BULGULAR}

Hastaların yarısı cerrahi yöntemle, yarısı da cerrahi dışı yöntemlerle tedavi edildi. Mükemmel ve iyi sonuçların oran $\% 50$ bulundu. İki taraflı yaralanması bulunan hastada avasküler nekroz gelişti. Bu hastada fonksiyonel sonuçlar kötü bulundu. Cerrahi ile tedavi edilen hastalardan birinde erken posttravmatik artrit görüldü, bu hastanın fonksiyonel sonuçları orta bulundu.

\section{SONUÇ}

Minimum yumuşak doku travması ile anatomik redüksiyonun sağlanması bu kırıkların tedavisindeki amacımız olmalıdır. Parçaların en iyi görüntüsü hangi yaklaşımla sağlanacaksa o yaklaşım tercih edilmelidir. Şu unutulmamalıdır ki, tüm tedavi seçeneklerine rağmen bu hastaların fonksiyonel sonuçları kötü olabilmektedir.

Anahtar Sözcükler: Femur başı; kırık; Pipkin; sonuçlar.
Femoral head fractures are seen in multitraumatized patients, especially after motor vehicle accidents. [1] They are very rare injuries. Keely and Lipscomb ${ }^{[2]}$ reported that the occurrence rate of femoral head fracture is two cases per one million per year. Therefore, more attention should be paid to the treatment of these patients.
The most common mechanism is dashboard injuries, in which the forces are transmitted through the shaft of the femur to the femoral head and acetabulum. [1] Traumatic posterior hip dislocations and femoral head injuries are common in this type of injury. ${ }^{[3]}$ The association of traumatic hip dislocation and femoral head fracture is variable in the literature $(4-17 \%) .{ }^{[4-12]}$ 
Treatment strategies in femoral head fractures are also controversial due to the low incidence of these fractures and the different classification systems used in the literature. ${ }^{[1,13]}$

In the past 20 months, we had six cases of femoral head fracture with or without acetabulum fracture. This is a very high incidence in this short time period. Therefore, we decided to discuss the treatment strategies based on our own experience to help optimize the treatment strategies of these fractures, in view of the controversies remaining in the literature on the classification and outcome of these injuries.

\section{MATERIALS AND METHODS}

We reviewed five patients (six fractures) who admitted to our emergency department due to femoral head fracture between March 2006 and December 2007. Medical data and radiographs including computerized tomography (CT), bone scan and magnetic resonance imaging (MRI) of the patients were reviewed for analysis. During the last follow-up, femoral head viability was investigated with MRI or bone scan. Each fracture was classified according to Pipkin, ${ }^{[14]}$ Brumback ${ }^{[13]}$ and $\mathrm{AO}^{[15]}$ classifications in order to evaluate the patients more precisely. Functional outcome was evaluated with the Merle d'Aubigne and Postel score ${ }^{[16]}$ and the Thompson and Epstein score.
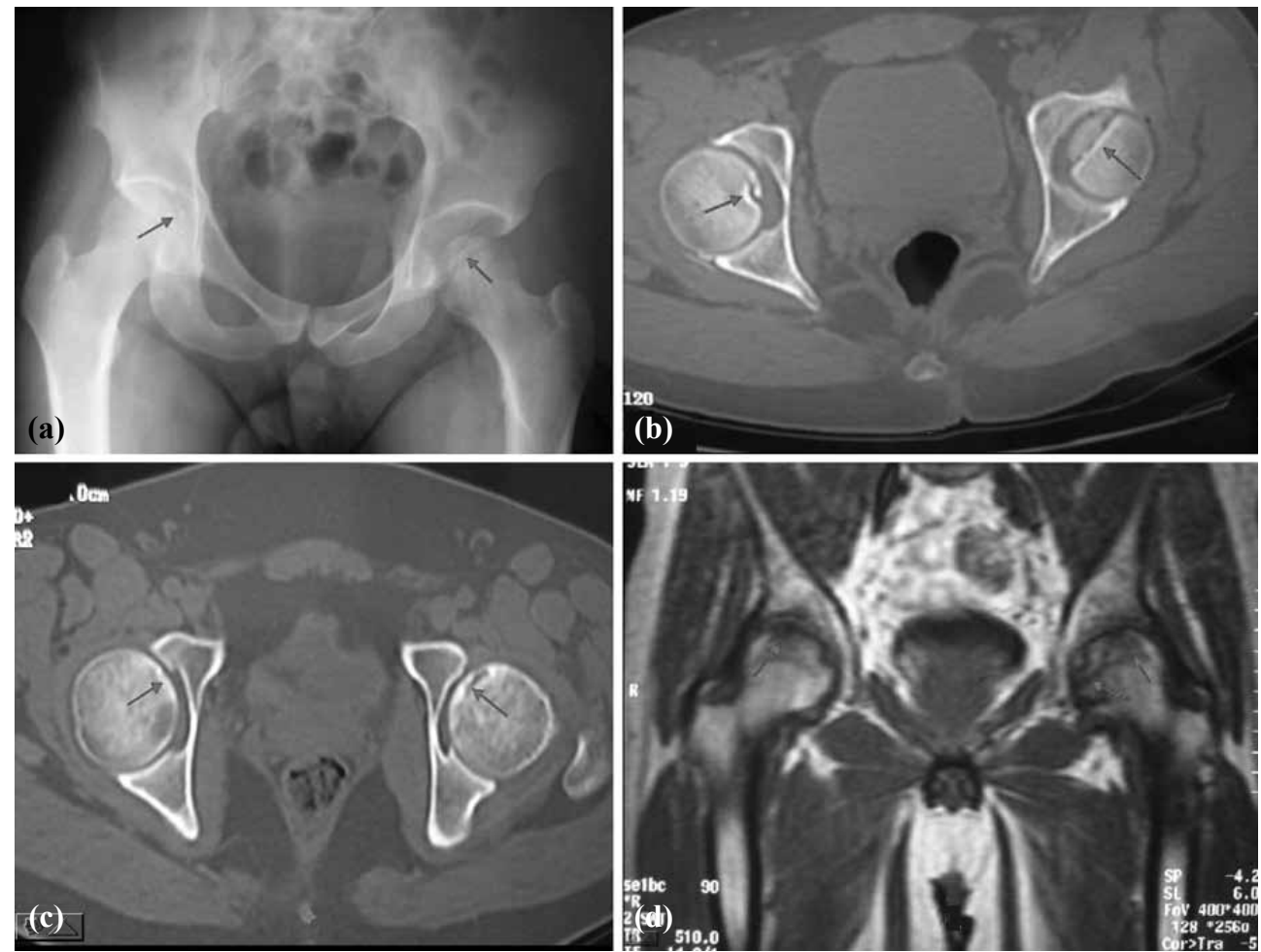

Fig. 1. This 21-year-old male patient was treated conservatively. Preoperative X-ray (a) and CT (b) of the patient showed the fractures on both sides (arrows). After one-year follow-up, we observed that the fractures were united (c); however, bilateral avascular necrosis of the femoral head was observed in the patient as seen in MRI (d). This patient had poor functional outcome.
[17] The Merle d'Aubigne and Postel score evaluates the hip function in three categories: pain, mobility and walking, with each section having a maximum score of 6 points. Eighteen points indicate excellent, 15-17 points good, $12-14$ points fair, and $<12$ points poor results. The Thompson and Epstein score evaluates functional and radiological outcome. Numeric scores are not used in this scoring system. Each of the functional and radiological outcome measurements are described as excellent, good, moderate or poor.

Complications like heterotopic ossification, avascular necrosis (AVN) and posttraumatic arthritis were also documented.

\section{RESULTS}

Five patients with six femoral head fractures were treated in our hospital between March 2006 and December 2007. Three of the fractures were stable with minimum displacement; therefore, they were treated nonoperatively (Figs. 1, 2), while three of them were treated with open reduction and internal fixation (ORIF) (Fig. 3). The average age at the time of injury was 28 (20-36) years. Most of the fractures were due to traffic accident; only one patient sustained injury from a motor vehicle accident. The fractures were classified and are summarized in Table 1 according to AO, Brumback and Pipkin classifications. All femoral head dislocations were reduced within the first 24 hours. We used Kocher-Langenbeck approach. The minimum follow-up was 16 months. One type I and two type II fracture dislocations according to Pipkin classification were treated nonoperatively. Two patients with Pipkin type II and one patient with type IV injury were treated with ORIF.

The overall outcomes were excellentgood in 3 fractures, fair in 1 and poor in 2 (Table 1). No sciatic nerve injury, deep wound infection or heterotopic ossification was observed. AVN was seen in 2 hips. This patient had bilateral injury and was treated nonoperatively. This pa- 

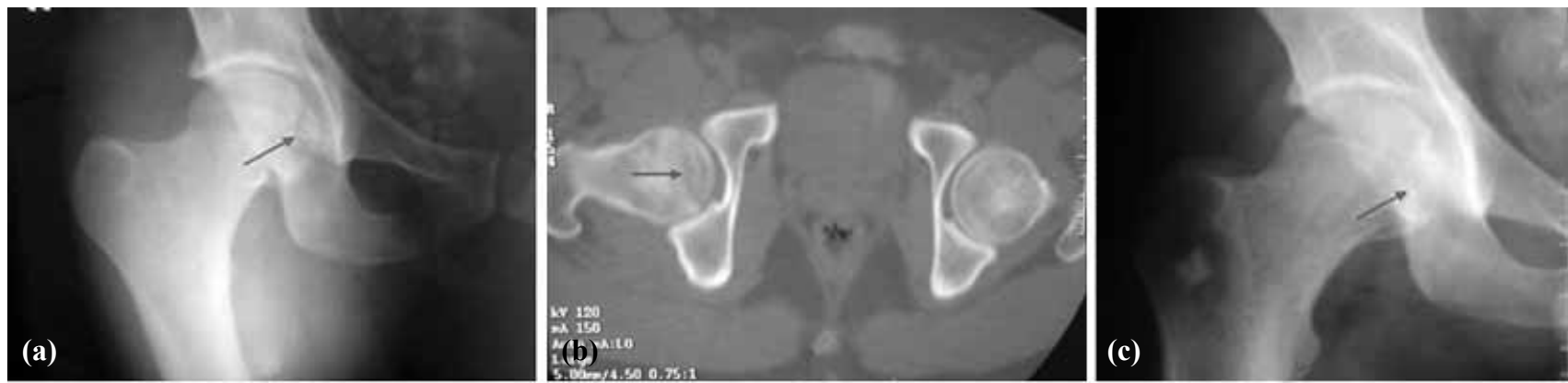

Fig. 2. This 29-year-old male patient was treated conservatively. Preoperative X-ray (a) and CT (b) of the patient showed Pipkin type II fracture (arrow). This patient healed without any complication with excellent functional outcome.

tient also had bilateral deep vein thrombosis despite low molecular weight heparin prophylaxis. All the fractures were united. In one of the operated patients, early posttraumatic arthritis developed. This patient is still being followed, and may require arthroplasty in the future.

\section{DISCUSSION}

Femoral head fractures are serious injuries. They are commonly seen after high-energy trauma following traumatic hip dislocation. Femoral head fracture dislocations are one of the few orthopedic emergen-
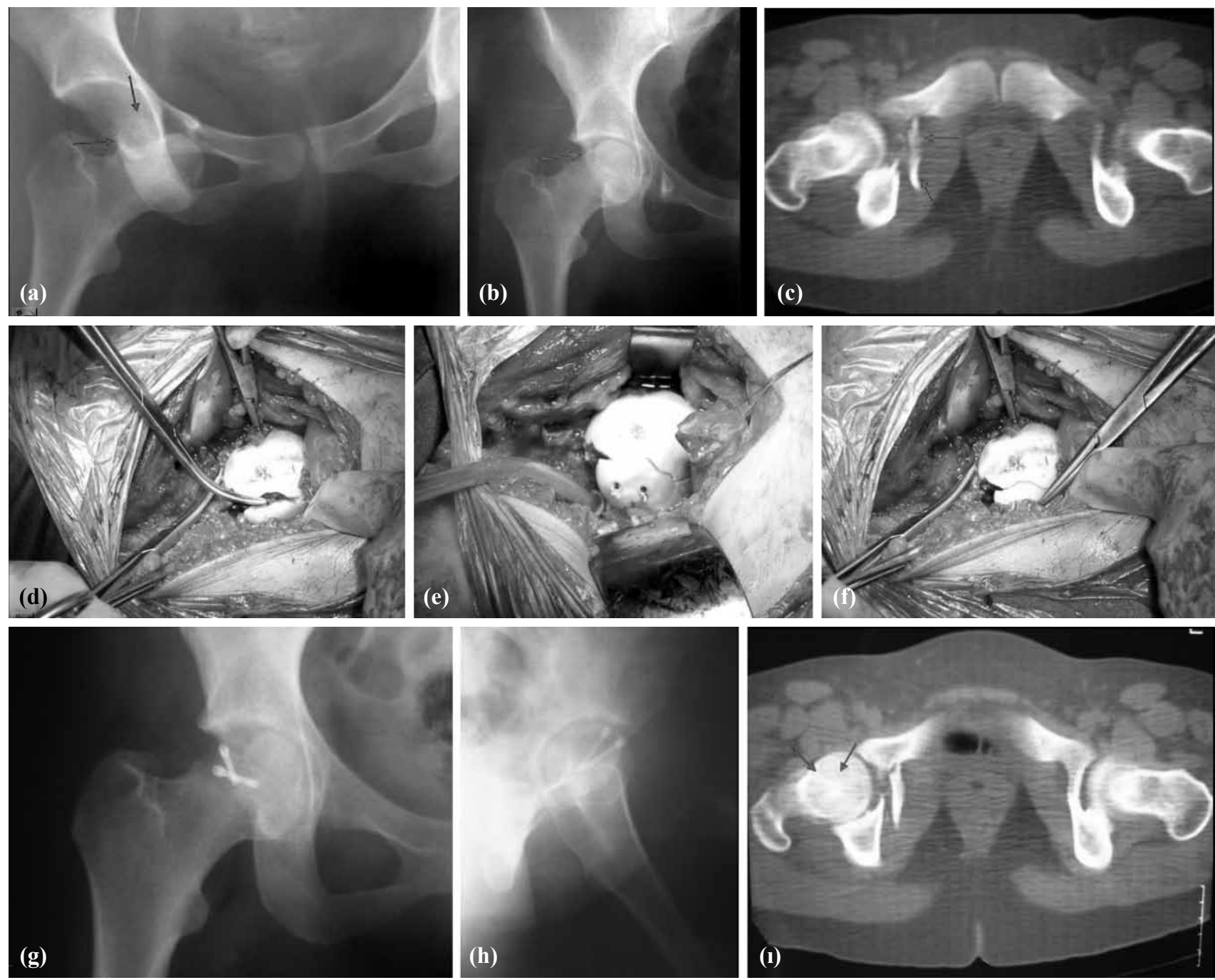

Fig. 3. This 20-year-old female patient had fracture dislocation of the hip joint. She had both acetabular fracture and fracture of the femoral head (Pipkin type IV). (a) The initial X-ray of the patient before the reduction of the hip joint. After reduction, we observed displaced femoral head fracture (b, c). Figs. (d-f) are intraoperative photographs of the patient. The fracture, reduction and fixation with two countersunk screws are seen. Figure (g) and (h) are postoperative X-rays of the patient. The anatomic reduction and fixation of the fragment can be seen. Postoperative CT also supports the quality of fixation (i). 
Table 1. Demographic data and results of the patients

\begin{tabular}{lcccccccccc}
\hline No & Age/Sex & Pipkin/Side & Brumback & AO & Treatment & Approach & Complication & Follow-up & M. d'Aub. & T\&E \\
\hline 1 & $29 / \mathrm{M}$ & II/R & 2A & C13 & Nonoperative & - & - & $28 \mathrm{~m}$ & Excellent & Excellent \\
2 & $34 / \mathrm{M}$ & II/R & 2B & C13 & ORIF & KL & PTA & $16 \mathrm{~m}$ & Fair & Fair \\
3 & $36 / \mathrm{M}$ & II/L & 2A & C13 & ORIF & KL & - & $16 \mathrm{~m}$ & Good & Good \\
4 & $20 / \mathrm{F}$ & IV/L & 2A & C13 & ORIF & KL & - & $32 \mathrm{~m}$ & Excellent Excellent & Ex \\
5 & $21 / \mathrm{M}$ & II/L & 2A & C13 & Nonoperative & - & AVN & $16 \mathrm{~m}$ & Poor & Poor \\
5 & $21 / \mathrm{M}$ & I/R & 1A & C12 & Nonoperative & - & AVN & $16 \mathrm{~m}$ & Poor & Poor \\
\hline
\end{tabular}

M. d'Aub: Merle d'Aubigne score; T\&E: Thompson and Epstein score; M: Male, F: Female; ORIF: Open reduction internal fixation; KL: Kocher-Langenbeck;

PTA: Post traumatic arthritis; AVN: Avascular necrosis; m: Months.

cies, and reduction must be done as soon as possible under general anesthesia with good muscle relaxation to prevent further damage. After reduction, careful examination on small-cut CT scans should be performed for reduction quality, comminution and free intraarticular fragments. ${ }^{[18]}$ MRI could also be added to the diagnostic tools for further evaluation of soft tissues, blood flow to the femoral head and cartilage damage. ${ }^{[19,20]}$ The information provided by these radiologic diagnostic modalities allows a complete understanding of the fracture pattern for the planning of further treatment.

Data about the outcome of the femoral head fractures reported in the literature are not evident. Similar to the literature, our series of femoral head fractures involved different fracture types and different treatment modalities. Since this trauma is rarely seen, the published series are small in number (5 patients in our series); Henle ${ }^{[21]}$ reported 12 patients over an 8-year period. Therefore, making a statistical analysis or any recommendation is almost impossible. For the same reason, prospective trials regarding outcome and treatment modalities are also not possible.

Definitive treatment should be planned according to the expectations, physiological status and well-being of the patient. Conservative treatment is accepted only when postreduction $\mathrm{CT}$ demonstrates anatomical reduction. ${ }^{[21]}$ Closed nonoperative treatment can be the best option for Pipkin type I and type II fractures. If closed reduction is not appropriate, ORIF should be the choice of treatment, excision of the fragments is the worst of all. ${ }^{[1]}$ These fractures are intraarticular fractures requiring anatomical reduction and stable fixation. Most of the patients will benefit more or less from surgical treatment. However, surgical treatment has some disadvantages. According to the literature, excellent and good results in Pipkin type I and type II fractures are achieved in more than $75 \%$ after closed treatment, while ORIF yields similar results in $65 \%$ of the cases. However, good or excellent results are achieved in only $50 \%$ of cases after excision of the fragments. ${ }^{[8,9,11-13,22-27]}$

Over the past decades, rates of excellent or good results of $40-70 \%$ have been published in the litera- ture. ${ }^{[8,22-24,28-31]}$ Our rate of excellent and good results was $50 \%$, which was similar to the literature. Two of the three patients who had excellent and good results were treated with ORIF. On the other hand, AVN was seen in two fractures; this patient was treated conservatively and had poor results. Therefore, we can say that the treatment modality is not associated with functional outcome in these injuries.

One of the factors affecting the outcome is surgical exposure. Although initial damage to the cartilage is the main factor in the determination of final outcome in femoral head fractures, poor results in many cases are related to the difficulties encountered in obtaining adequate exposure, reduction and osteosynthesis. ${ }^{[1]}$ Three surgical approaches are advocated in the literature: anterolateral (Watson-Jones), ${ }^{[22,24,32]}$ anterior (Smith-Patterson) ${ }^{[24,25,31]}$ and posterior (Kocher-Langenbeck). ${ }^{[26]}$ Anterior approaches are related with high rates of heterotopic ossification, but obtain an optimal exposure of the fragments of the femoral head. ${ }^{[1]}$ Swiontkowski et al. ${ }^{[33]}$ compared anterior versus posterior approach in the treatment of Pipkin type I and II fractures. They found that anterior approach caused less blood loss, shorter operation time and better visualization but more heterotopic ossification. Another criticism of the anterior approach is that it will damage the remaining anterior blood supply. ${ }^{[6,7,29]}$

We treated three patients $(50 \%)$ operatively. We used posterior Kocher-Langenbeck approach for operations. Although it is reported that the anterior (Smith-Patterson) approach is associated with less blood loss, shorter operation time and better visualization, the functional outcomes were identical for both procedures. ${ }^{[33]}$ One of the disadvantages of the anterior approach is deterioration of the remaining anterior blood circulation after posterior dislocation and the associated posterior circulatory loss; ${ }^{[29]}$ however, Stockenhuber et al. ${ }^{[22]}$ showed that there is little or no interference with the blood supply of the femoral head via this approach. On the other hand, the posterior approach is associated with additional damage to the posterior circulation, which was deteriorated after posterior dislocation and has potential for AVN. However, the posterior approach is recommended for 
Pipkin type IV fractures. Simultaneous repair of both the posterior wall of the acetabulum and femoral head can be achieved in this way. ${ }^{[28,32]}$ We used the posterior approach for the operations without any major intraoperative complications. AVN was not seen in our operatively treated patients. We also observed no postoperative heterotopic ossification. In our opinion, the experience of the surgeon is the key point for the success of the operation rather than the technique itself.

Recently, favorable results with trochanteric flip osteotomy and ORIF of the femoral head have been published; however, their overall excellent or good results did not differ much from the literature. ${ }^{[1,21]}$ The increased morbidity of this operation should also be remembered. Therefore, we can say that every fracture of the femoral head should not promptly be treated with ORIF. Additional damage done during surgical interventions must not be forgotten. The treatment of choice should be well explained to the patient and expectations of the patients should be taken into consideration. ORIF does not mean excellent results; patients may also benefit from conservative treatment strategies. We should not forget that we cannot control the injury at the time of impaction. Perhaps that is the main key of all treatment strategies; this must be investigated further.

Fixation methods are variable. We used $2 \mathrm{~mm}$ countersunk titanium minifragment screws for the fixation in our patients without any problem. Some authors ${ }^{[23,34]}$ advocated titanium or Herbert screws for MRI compatibility. Biodegradable screws have also been used successfully. ${ }^{[9]}$ Total hip replacement should be chosen for elderly patients with Pipkin type III fractures. Excision of the fragment was recommended by Epstein $^{[6,7,29]}$ in the 1970s, however, maintaining joint congruity is a prerequisite for a good outcome, which is reinforced by more recent studies. ${ }^{[5,8,24,25]}$

We believe that the poor outcome of these patients is mostly due to major complications. These complications included AVN of the femoral head (0-24\%), posttraumatic osteoarthritis $(0-72 \%)$, peripheral nerve damage (7-27\%). and heterotopic ossification (2$54 \%){ }^{[1,21]}$ In our patient group, AVN was seen in two fractures and posttraumatic arthritis in one. AVN can be caused by the damage at the time of impaction or it can be iatrogenic. Care should be taken during reduction of the hip with gentle maneuvers to prevent further vascular impairment.

AVN and posttraumatic arthritis are serious complications and can be treated with joint replacement. Some authors even recommend total hip replacement as the initial treatment for Pipkin type III fractures; however, this is justifiable only for older patients. Total joint replacement or hip arthrodesis can only be recommended after the failure of ORIF. We are still following our patients who had serious complications, and they may require further surgery.

Although we observed no heterotopic ossification, its incidence is not low. ${ }^{[35]}$ It is mostly seen after intracranial injury in multitrauma patients. These patients can be treated with indomethacin or low-dose irradiation for prophylaxis.

It is believed that every effort should be attempted for the preservation of the joint. Despite the modern treatment modalities and increased technology, most of these patients develop some degree of joint arthritis or joint pain. If we cannot protect the joint, hip arthrodesis is the best option for young patients; for the elderly, total hip replacement seems to be the best choice.

We think that functional results are not directly related to the treatment modality. The severity of the injury, general health of the patient, timing of the surgery, timing of admission to the hospital, timing of reduction of the hip dislocation, injury at the time of impaction, cartilage injury, and subchondral collapse are all important factors that affect the outcome in these patients.

In conclusion, we believe that newer technologies and techniques will improve the outcome of femoral head fractures in the coming decades. In the treatment, we should aim at anatomic reduction of the fragments with minimum soft tissue injury. When surgery is required, we should choose the best approach for excellent view of the fragments. Lastly, we should not forget that half of these patients will have a poor outcome despite all treatment strategies.

\section{REFERENCES}

1. Kloen P, Siebenrock KA, Raaymakers ELFB, Marti RK, Ganz R. Femoral head feactures revisited. European Journal of Trauma 2002;4:221-3.

2. Kelly PJ, Lipscomb PR. Primary vitallium-mold arthroplasty for posterior dislocation of the hip with fracture of the femoral head. J Bone Joint Surg [Am] 1958;40:675-80.

3. Funsten RV, Kinser P, Frankel CJ. Dashboard dislocation of the hip: a report of twenty cases of traumatic dislocation. J Bone Joint Surg 1938;20:124-32.

4. Armstrong JR. Traumatic dislocation of the hip joint; review of 101 dislocations. J Bone Joint Surg [Br] 1948;30:430-45.

5. Butler JE. Pipkin Type-II fractures of the femoral head. J Bone Joint Surg Am 1981;63:1292-6.

6. Epstein HC. Posterior fracture-dislocations of the hip; longterm follow-up. J Bone Joint Surg [Am] 1974;56:1103-27.

7. Epstein HC. Posterior fracture dislocations of the hip. J Bone Joint Surg [Am] 1961;43:1079-1098

8. Hougaard K, Thomsen PB. Traumatic posterior fracture-dislocation of the hip with fracture of the femoral head or neck, or both. J Bone Joint Surg [Am] 1988;70:233-9.

9. Jukkala-Partio K, Partio EK, Hirvensalo E, Rokkanen P. Absorbable fixation of femoral head fractures. A prospective 
study of six cases. Ann Chir Gynaecol 1998;87:44-8.

10. Kelly RP, Yarbrough SH 3rd. Posterior fracture-dislocation of the femoral head with retained medial head fragment. J Trauma 1971;11:97-108.

11. Lang-Stevenson A, Getty GJM. The Pipkin fracture dislocation of the hip. Injury 1987;18:264-69.

12. Roeder LF Jr, DeLee JC. Femoral head fractures associated with posterior hip dislocation. Clin Orthop Relat Res 1980:121-30.

13. Brumback RJ, Kenzora JE, Levitt LE, Burgess AR, Poka A. Fractures of the femoral head. Hip 1987:181-206.

14. Pipkin G. Treatment of grade IV fracture-dislocation of the hip. J Bone Joint Surg [Am] 1957;39:1027-42

15. Ganz R. Proximal femur. In: Müller ME, Allgöwer M, Schneider $\mathrm{R}$, Willenegger $\mathrm{H}$, editors. Manual of internal fixation. Techniques recommended by the AO-ASIF group. Berlin: Springer; 1992. p. 519-21.

16. Merle d'Aubigné R, Postel M. Functional hip arthroplasty with acrylic prosthesis. J Bone Joint Surg [Br] 1954;36:45175.

17. Thompson VP, Epstein HC. Traumatic dislocation of the hip; a survey of two hundred and four cases covering a period of twenty-one years. J Bone Joint Surg [Am] 1951;33:746-78.

18. Moed BR, Maxey JW. Evaluation of fractures of the femoral head using the CT-directed pelvic oblique radiograph. Clin Orthop Relat Res 1993:161-7.

19. Potter HG, Montgomery KD, Heise CW, Helfet DL. MR imaging of acetabular fractures: value in detecting femoral head injury, intraarticular fragments, and sciatic nerve injury. AJR Am J Roentgenol 1994;163:881-6.

20. Horii M, Kubo T, Hirasawa Y. Radial MRI of the hip with moderate osteoarthritis. J Bone Joint Surg [Br] 2000;82:364-8.

21. Henle P, Kloen P, Siebenrock KA. Femoral head injuries: Which treatment strategy can be recommended? Injury 2007;38:478-88.

22. Stockenhuber N, Schweighofer F, Seibert FJ. Diagnosis, therapy and prognosis of Pipkin fractures (femur head dislocation fractures) Chirurg 1994;65:976-82. [Abstract]

23. Marchetti ME, Steinberg GG, Coumas JM. Intermediateterm experience of Pipkin fracture-dislocations of the hip. J
Orthop Trauma 1996;10:455-61.

24. Schönweiss T, Wagner S, Mayr E, Rüter A. Late results after fracture of the femoral head. Unfallchirurg 1999;102:776-83. [Abstract]

25. Mowery C, Gershuni DH. Fracture dislocation of the femoral head treated by open reduction and internal fixation. J Trauma 1986;26:1041-4.

26. Vermeiren JA, van Hoye M. Three cases of femoral head fracture in a single car accident. J Trauma 1991;31:579-81.

27. Weigand H. Combination injuries of the hip joint including shear fractures of the femoral head. Aktuelle Traumatol 1980;10:1-8.

28. Dreinhöfer KE, Schwarzkopf SR, Haas NP, Tscherne H. Femur head dislocation fractures. Long-term outcome of conservative and surgical therapy. Unfallchirurg 1996;99:400-9. [Abstract]

29. Epstein HC, Wiss DA, Cozen L. Posterior fracture dislocation of the hip with fractures of the femoral head. Clin Orthop Relat Res 1985;(201):9-17.

30. Sahin V, Karakaş ES, Aksu S, Atlihan D, Turk CY, Halici M. Traumatic dislocation and fracture-dislocation of the hip: a long-term follow-up study. J Trauma 2003;54:520-9.

31. Stannard JP, Harris HW, Volgas DA, Alonso JE. Functional outcome of patients with femoral head fractures associated with hip dislocations. Clin Orthop Relat Res 2000:44-56.

32. Duquennoy A, Decoulx J, Capron JC, Torabi DJ. Traumatic dislocations of the hip with fracture of the femur head. Apropos of 28 cases. Rev Chir Orthop Reparatrice Appar Mot 1975;61:209-19. [Abstract]

33. Swiontkowski MF, Thorpe M, Seiler JG, Hansen ST. Operative management of displaced femoral head fractures: casematched comparison of anterior versus posterior approaches for Pipkin I and Pipkin II fractures. J Orthop Trauma 1992;6:437-42.

34. Murray P, McGee HM, Mulvihill N. Fixation of femoral head fractures using the Herbert screw. Injury 1988;19:220-1.

35. Boes M, Kain M, Kakar S, Nicholls F, Cullinane D, Gerstenfeld L, et al. Osteogenic effects of traumatic brain injury on experimental fracture-healing. J Bone Joint Surg [Am] 2006;88:738-43. 